University of Nebraska - Lincoln

DigitalCommons@University of Nebraska - Lincoln

\title{
Movements and Home Ranges of White-Tailed Deer in Response to Roadside Fences
}

\author{
William D. Gulsby \\ University of Georgia \\ Daniel W. Stull \\ University of Georgia \\ George R. Gallagher \\ Berry College \\ David A. Osborn \\ University of Georgia \\ Robert J. Warren \\ University of Georgia \\ See next page for additional authors
}

Follow this and additional works at: https://digitalcommons.unl.edu/usarmyresearch

Gulsby, William D.; Stull, Daniel W.; Gallagher, George R.; Osborn, David A.; Warren, Robert J.; Miller, Karl V.; and Tannenbaum, Lawrence V., "Movements and Home Ranges of White-Tailed Deer in Response to Roadside Fences" (2011). US Army Research. 244.

https://digitalcommons.unl.edu/usarmyresearch/244

This Article is brought to you for free and open access by the U.S. Department of Defense at DigitalCommons@University of Nebraska - Lincoln. It has been accepted for inclusion in US Army Research by an authorized administrator of DigitalCommons@University of Nebraska - Lincoln. 


\section{Authors}

William D. Gulsby, Daniel W. Stull, George R. Gallagher, David A. Osborn, Robert J. Warren, Karl V. Miller, and Lawrence V. Tannenbaum 
Original Article

\title{
Movements and Home Ranges of White-Tailed Deer in Response to Roadside Fences
}

\author{
WILLIAM D. GULSBY, ${ }^{1}$ Warnell School of Forestry and Natural Resources, University of Georgia, Athens, GA 30602, USA \\ DANIEL W. STULL, Warnell School of Forestry and Natural Resources, University of Georgia, Athens, GA 30602, USA \\ GEORGE R. GALLAGHER, Department of Animal Science, Berry College, Mount Berry, GA 30149, USA \\ DAVID A. OSBORN, Warnell School of Forestry and Natural Resources, University of Georgia, Athens, GA 30602, USA \\ ROBERT J. WARREN, Warnell School of Forestry and Natural Resources, University of Georgia, Athens, GA 30602, USA \\ KARL V. MILLER, Warnell School of Forestry and Natural Resources, University of Georgia, Athens, GA 30602, USA \\ LAWRENCE V. TANNENBAUM, Environmental Health Risk Assessment Program, U.S. Army Institute of Public Health, \\ Aberdeen Proving Ground, MD 21010, USA
}

\begin{abstract}
Although roadside fences have been proven effective at reducing deer-vehicle collisions (DVCs), information on how these fences alter deer behavior is lacking. We evaluated the effects of a traditional and a novel fencing design, constructed alongside a roadway, on movements and home ranges of white-tailed deer (Odocoileus virginianus). From January to April 2009, we fitted 14 adult female deer with Global Positioning System collars, programmed to collect $\geq 24$ locations/day. In June 2009 we constructed a $3.2-\mathrm{km}$ fence that included a $1.6-\mathrm{km}$ section of $2.4-\mathrm{m}$ vertical-wire fence and a $1.6-\mathrm{km}$ section of a prototype outrigger fence (i.e., $0.6 \mathrm{~m}$, shade-cloth [50\% opaque plastic sheeting] on a $45^{\circ}$ outrigger angled toward the deer attached to the top of a $1.2 \mathrm{~m}$, vertical-wire fence). We retrieved collars between January and March 2010. We compared home ranges, fence crossings, and fence circumventions among deer that encountered the outrigger and 2.4-m fences as well as for deer that encountered neither fence (i.e., controls), before and after fence construction. Actual crossings of the fence area were reduced, postconstruction, by $98 \%$ and $90 \%$ for the $2.4 \mathrm{~m}$ and outrigger treatment groups, respectively, suggesting that the fences were sufficiently effective to simulate how deer respond to roadside barriers. Deer with pretreatment home ranges that approached or encompassed the fence endings maintained a high degree of site fidelity by circumventing the endings. This study highlights the importance of incorporating information on deer behavior and resource usage into DVC-reduction strategies. If these factors are not accounted for, DVC frequency will likely stay the same, or increase, near fence endings. Thus, roadside fences should likely end at natural barriers to deer movements (i.e., heavy development) or incorporate some means of safe crossing into their endings. (c) 2011 The Wildlife Society.

This article is a U.S. government work, and is not subject to copyright in the United States.
\end{abstract}

KEY WORDS deer-human interactions, deer-vehicle collisions, fencing, Georgia, GPS, Odocoileus virginianus, roads, white-tailed deer, wildlife damage management, wildlife-vehicle collisions.

Abundant white-tailed deer (Odocoileus virginianus) populations, an expanding roadway system, and increased vehicular traffic have resulted in an increase in deer-vehicle collisions (DVCs) in many areas of the United States (Romin and Bissonette 1996). An estimated 1.5 million DVCs (Conover et al. 1995) occur each year in the United States, resulting in US $\$ 1.1$ billion in vehicle damages and as many as 200 human fatalities/yr (State Farm Insurance Company 2009). According to the Insurance Information Institute (2008), the average insurance claim for damage incurred from a DVC is US $\$ 2,800$. When medical costs for bodily injury are included, the average

Received: 28 December 2010; Accepted: 7 May 2011

${ }^{1}$ E-mail: gulsbyw@warnell.uga.edu cost increases to US $\$ 10,000$. The Georgia Department of Natural Resources, Wildlife Resources Division estimates that as many as 51,000 DVCs occur each year in Georgia, USA, accounting for $13.5 \%$ of all collisions in the state (Bowers et al. 2005).

Devices and strategies promoted to reduce DVCs include animal-detection systems, vehicle-mounted sound-production systems, exclusion fences, herd reduction, intercept feeding, roadway lighting, roadside reflectors, roadway signage, and wildlife underpasses or overpasses. Of these, exclusion fencing is perhaps the most frequently utilized and studied. Although the construction costs of deer-proof fencing are high, it is the most economical and effective option when deer-damage tolerance is low, as is the case in areas with high incidence of DVCs (Bashore et al. 1985, Bryant et al. 1993, Craven and Hygnstrom 1994, DeNicola et al. 
2000, VerCauteren et al. 2006). Huijser et al. (2007) estimated the cost of DVC-mitigation fencing to be US $\$ 3,760$ / $\mathrm{km} / \mathrm{yr}$ (assuming a lifespan of $25 \mathrm{yr}$, not including maintenance) with a benefit (e.g., collisions prevented as a result of the fencing) of US $\$ 32,728 / \mathrm{km} / \mathrm{yr}$.

Woven-wire fencing $\geq 2.4 \mathrm{~m}$ in height is effective in preventing deer crossings (Bryant et al. 1993, Craven and Hygnstrom 1994, Seamans 2001, Kaneene et al. 2002, VerCauteren et al. 2006). However, alternative fencing designs such as angled fences and outrigger fences also have proven effective at reducing deer crossings. For example, Jones and Longhurst (1958) tested a 0.6-m vertical fence with a $1.8-\mathrm{m}$ outrigger angled at $25^{\circ}$ and a $1.2-\mathrm{m}$ vertical fence with a $1.2-\mathrm{m}$ outrigger angled at $45^{\circ}$. In both cases, deer were more likely to attempt to go under the fence when the outrigger was angled toward them. Similarly, Stull (2009) found that a 1.2-m woven-wire fence with a $0.6-\mathrm{m}$ $50 \%$ opaque plastic outrigger angled at $45^{\circ}$ acted as a 1-way barrier, meaning deer were less likely to cross when the outrigger was angled toward them. However, maximum effectiveness of any fence design requires that the fence is properly constructed and maintained, located on both sides of the road, is of sufficient length to extend beyond the home ranges of deer in high-risk areas, and has some way for animals to escape from the right-of-way should they breach the barrier (Knapp et al. 2004, Huijser et al. 2007).

Fencing trials conducted on captive deer allow direct observation of crossing events and increased experimental control, but fail to account for the potential consequences that result from excluding deer from portions of their home ranges. For example, a deer that is excluded from a portion of its home range may concentrate its activity in another area or circumvent the barrier, thereby potentially increasing DVCs elsewhere (Owen and Owen 1980, Isleib 1995, Clevenger et al. 2001, VerCauteren et al. 2006). Past research conducted along roadsides has given some indication of how deer respond to barriers, but these studies have typically done so using indirect measures such as carcass counts, track counts, or surveys of deer in the right-of-way (Puglisi et al. 1974, Carbaugh et al. 1975, Falk et al. 1978, Clevenger et al. 2001). To the best of our knowledge, only Feldhamer et al. (1986) have directly studied deer movements in relation to roadside fencing. However, because deer movements in Feldhamer et al. (1986) were monitored using very high frequency (VHF) telemetry, the investigators lacked the fine-scale data needed to quantify the effects of the fencing on daily deer movements.

The combination of widespread use of roadside fencing and the lack of knowledge surrounding how deer respond to these fences could potentially exacerbate deer-vehicle interactions. Herein, we report on a study of a prototype fencing design, compare its efficacy to a commonly used fence design, and determine their effects on home ranges and movements of free-ranging deer.

\section{STUDY AREA}

We conducted our study on the Berry College Wildlife Refuge (BCWR) within the 11,340-ha Berry College
Campus in northwestern Georgia. The 1,215-ha refuge was located in the Ridge and Valley physiographic province (Hodler and Schretter 1986) with elevations ranging from $172 \mathrm{~m}$ to $518 \mathrm{~m}$. Hunting was prohibited on the refuge, for $>40 \mathrm{yr}$, and deer were abundant, with an estimated density of 40 deer $/ \mathrm{km}^{2}$ (J. Beardon, Georgia Department of Natural Resources, personal communication). As a result, 12-24 DVCs were reported annually, although the actual number of collisions was likely higher (Berry College Police Department, unpublished data).

The campus was divided into the main campus and the mountain campus. Both campuses were characterized by buildings and facilities interspersed with pastures, woodlots, and manicured lawns. They were connected by a $4.8-\mathrm{km}$ road known as Lavender Mountain Road (LMR). This was a straight, 2-lane blacktop road with a speed limit ranging from $40 \mathrm{~km} / \mathrm{hr}$ to $64 \mathrm{~km} / \mathrm{hr}$. Running parallel to LMR was a power-line right-of-way known as the Viking Trail (VT). The area surrounding LMR and the VT was forested and consisted of pine stands (Pinus taeda and P. palustris) and mixed forest dominated by oaks (Quercus spp.), hickories (Carya spp.), and pines. Lavender Mountain Road and the VT were separated by a strip of mixed forest that ranged from $30 \mathrm{~m}$ to $125 \mathrm{~m}$ wide. We selected the VT as the construction site for the roadside fencing because it was open, flat, straight, and simulated a common situation where a roadway travels through a wooded area harboring an abundant deer population.

\section{METHODS}

During January to April 2009, we fitted 10 adult female deer ( $\geq 1.5$-yr old) with Televilt Tellus ${ }^{\circledR}$, 5H1D (Televilt/TVP Positioning AB, Lindesberg, Sweden) and 4 with Lotek 3300L (Lotek Engineering, ON, Canada) Global Positioning System (GPS) collars. We captured deer using either dart projectors or rocket nets. When darting, we used 2-mL transmitter darts (Pneu-Dart, Inc., Williamsport, PA) to intramuscularly inject a Telazol ${ }^{\circledR}(300 \mathrm{mg}$; Fort Dodge Animal Health, Fort Dodge, IA)-xylazine hydrochloride (400 mg; Congaree Veterinary Pharmacy, Cayce, SC) combination to immobilize deer. We immobilized deer captured in rocket nets with an intramuscular Telazol-xylazine hydrochloride $(100 \mathrm{mg} / 320 \mathrm{mg})$ injection. We calculated dosages assuming an average deer weight of $45 \mathrm{~kg}$. During immobilization, we monitored vital signs, treated minor injuries, lubricated eyes, and blindfolded each deer. After $90 \mathrm{~min}$, we administered a 100-mg injection (50 mg [IV] $+50 \mathrm{mg}$ [IM]) of yohimbine hydrochloride (Antagonil $^{\circledR}$, Wildlife Laboratories, Fort Collins, CO) to reverse the effects of the xylazine hydrochloride. We monitored all deer until they were ambulatory. Animal handling procedures were approved by the University of Georgia Institutional Animal Care and Use Committee (no. A2007-10127-0).

We programmed the GPS collars to collect and store GPS locations (in the form of $X, Y$ coordinates) on their nonvolatile memory. We programmed Lotek collars to collect 48 locations/day at equal intervals throughout the study 
period. Because of battery-life limitations, we programmed Televilt collars to collect 48 locations/day at equal intervals from 1 January to 30 June (immediately before and after fence construction) and 24 locations/day at equal intervals from 1 July to 31 December. For all statistical comparisons between collar brands, we filtered data to ensure equal sampling frequencies. Collars were equipped with mortality sensors that emitted a double-pulse VHF beacon after $8 \mathrm{hr}$ of inactivity. We monitored deer once per week using VHF-telemetry equipment to ensure they were alive and that collars were functioning properly. If a mortality signal was detected, the collar was retrieved immediately. We recovered collars from January to March 2010 by activating a remoterelease mechanism that caused functioning collars to fall from the deer. The release mechanisms failed on 9 collars, so we retrieved these collars via lethal means (gunshot). We used the Televilt Tellus TPM Project Manager software (Televilt/TVP Positioning AB) and the Lotek GPS 3000 Host Application (Lotek Wireless, Inc., Newmarket, ON, Canada) to download data. To decrease the probability of erroneous points in the datasets, we filtered out any points representing nonfixes, impossible locations, and locations with dilution of precision values $>6$. After data censoring, we imported GPS fixes for each deer into ArcMap 9.3 (Environmental Systems Research Institute, Inc., Redlands, CA) and projected them in Universal Transverse Mercator North American Datum 1983 Zone 17 North (m).

Construction of the $3.2-\mathrm{km}$ fence treatment along the VT began on 18 May 2009 and ended on 10 June 2009. The fence included a $1.6-\mathrm{km}$ section of $2.4-\mathrm{m}$ woven wire (Solidlock ${ }^{\circledR}$ Game Fence; Bekaert Corporation, Marietta, GA) to which we attached a $1.6-\mathrm{km}$ section of the outrigger fence. The outrigger fence consisted of $1.2-\mathrm{m}$ woven wire (Solidlock Game Fence) with 0.6-m-long outriggers (Hearne Steel Company, Hearne, TX) attached to the top, and angled at $45^{\circ}$ away from the road. We threaded 5 strands of white Bayco ${ }^{\circledR}$ Finish Line wire (Ag-liner, Inc., Mars, PA) into precut slots spaced $12.5 \mathrm{~cm}$ apart on the outriggers. Total construction costs were US $\$ 9,356 / \mathrm{km}$ (US $\$ 9.36 / \mathrm{m}$ ) and US $\$ 7,370 / \mathrm{km}$ (US $\$ 7.37 / \mathrm{m}$ ) for the 2.4- $\mathrm{m}$ and outrigger fences, respectively.

We assigned each deer to outrigger fence $(n=4)$ or $2.4-\mathrm{m}$ fence $(n=4)$ treatment groups according to the fence design that their home range overlapped. These experimental groups were independent, because no deer had a home range that overlapped both fence designs. We selected 6 collared deer with home ranges that did not overlap either fence design as our experimental control group. We structured the dataset for each treatment group into 3 time blocks based on when the fence was constructed, and to account for expected seasonal changes in home range size. We defined the pretreatment period as the duration from the date when deer were collared until the date immediately before fence construction began. We defined the first posttreatment period (posttreatment 1) as 11 June to 11 September 2009. This period was designed to assess the immediate effects of each fence design on deer movements and home ranges. This treatment period also included fawning season, when home ranges of adult females are known to decrease in size. We defined the posttreatment 2 period as 12 September 2009 until collar recovery. Sample sizes during this period were 3 and 2 for the outrigger and 2.4-m fence treatments, respectively, because of 2 premature collar failures and 1 deer mortality that was not related to the experiment.

To assess the impacts of the fences on deer home ranges and core areas, we calculated $90 \%$ home ranges and $50 \%$ core areas for each deer during each treatment period. Home ranges and core areas were constructed using the adaptivelocal convex hull $(a-\mathrm{LoCoH})$ method in the Adehabitat Package (Calenge 2006) for the $\mathrm{R}$ software version 2.10.1 (R Development Core Team 2009). We selected $a$-LoCoH over a parametric kernel method because of its ability to capture hard boundaries (e.g., fences or roadways) to animal movements. For a more thorough review of $a-\mathrm{LoCoH}$, see Getz et al. (2007). Because this method of home range estimation is computer-intensive, we removed non-top hour fixes (i.e., those occurring on the half-hour) from each dataset to expedite processing. The resulting datasets contained far greater than the minimum number of 10 positions/animal/month recommended by Börger et al. (2006). We used the maximum distance between any 2 points in the data set as the starting point for $a$ (Getz et al. 2007), then examined plots of the area covered by a particular utilization distribution against a wide range of values of $a$. When the plot of the estimated area stabilized, we assumed all spurious holes (i.e., those representing an artifact of the algorithm rather than an actual area of nonuse) in the utilization distributions were covered, and selected this value of $a$ (Getz and Wilmers 2004, Ryan et al. 2006). We compared mean home range and core area sizes among treatment groups and periods. We considered means with nonoverlapping standard errors as significantly different.

We used "Mean Center" in ArcToolbox (Environmental Research Systems Institute, Inc.) to calculate the mean geographic center of fixes for each deer during each treatment period. We then measured the distance between the mean of center points for each deer from pretreatment to posttreatment 1 and from posttreatment 1 to posttreatment 2 . We compared mean shifts in the geographic center of fixes among treatment groups and periods. We considered means with nonoverlapping standard errors as significantly different.

To determine the efficacy of each fence design, we identified and quantified crossing events by examining the daily movement paths of each deer before versus after fence construction. We used several criteria to differentiate actual crossings from spurious (i.e., the result of GPS-location error) ones. When a deer's movement path crossed the fence, we classified the event as a crossing if the following criteria were met: 1) $\geq 2$ sequential locations occurred on the opposite side and $\geq 20 \mathrm{~m}$ from the fence during the 1-hr sampling frequency; 2) $\geq 3$ sequential locations occurred on the opposite side and $\geq 20 \mathrm{~m}$ from the fence during the 30 -min sampling frequency. An event was recorded as a circumvention when a distinct movement path around the fence end 
was observed. We recorded the date and time of each crossing and circumvention and also recorded the direction of crossing (i.e., outrigger toward vs. away) for the outrigger fence. To account for the difference in duration of pre- versus postconstruction periods, we calculated the average number of crossing events per sample day (crossings/day) for each deer, before and after fence construction, by dividing the total number of crossing events by the number of sample days in each treatment period. We used repeated-measures ANOVA to compare the efficacies of the outrigger toward, outrigger away, and the $2.4-\mathrm{m}$ treatments.

We also compared the distribution of each deer's point locations relative to the fences, for each treatment period. We used "Multiple Ring Buffer" in ArcToolbox (Environmental Research Systems Institute, Inc.) to create 50-m-wide linear buffers, starting directly adjacent to each fence and radiating out to $650 \mathrm{~m}$, on both sides of the fence. We then joined these buffer polygons to the point layer of each deer for each treatment period, and divided the sum of point locations occurring in each $50-\mathrm{m}$ buffer by the total number of point locations contained in the entire multiple-ring buffer to calculate the proportion of points occurring in each buffer.

\section{RESULTS}

Deer with home ranges interrupted by the $2.4-\mathrm{m}$ fence $(n=4)$ crossed the VT 124 times before fence construction, and only 2 times after fence construction (98\% reduction). One deer (no. 20) was responsible for both of the documented 2.4-m fence crossings. She crossed the fence, remained on the opposite side for $2 \mathrm{hr}$, then crossed back. On average $( \pm$ SE), deer crossed the VT $0.337 \pm$ 0.09 times/day before construction of the $2.4-\mathrm{m}$ fence, and $0.002 \pm 0.002$ times/day after construction.

Efficacy of the outrigger fence did not differ when the outrigger angled toward (outrigger toward) versus away (outrigger away) from the deer $\left(F_{1,6}=1.46, P=0.27\right)$. Therefore, we pooled outrigger fence crossing data for comparison with the $2.4-\mathrm{m}$ fence. Deer encountering the outrigger-fence $(n=4)$ crossed the VT 228 times before fence construction, and 22 times after fence construction $(90 \%$ reduction). On average $( \pm \mathrm{SE})$, deer crossed the VT $1.02 \pm 0.26$ times/day before construction of the outrigger fence and $0.05 \pm 0.035$ times/day after construction.

Mean crossings/day decreased posttreatment for both treatment groups $\left(F_{1,6}=20.10, P=0.004\right)$, but the 2.4 $\mathrm{m}$ fence was more effective than the outrigger fence $\left(F_{1,6}=7.96, P=0.03\right)$ at preventing crossings.

During the postfence construction periods, we documented 50 and 54 circumvention events for the $2.4-\mathrm{m}$ and outrigger fences, respectively. One deer (no. 20), whose home range extended beyond the fence during posttreatment 2 was responsible for all of the 2.4-m circumventions (Fig. 1). Three of 4 deer (nos. 1, 10, and 19) were responsible for the 54 recorded outrigger circumventions. Each of these deer had posttreatment home ranges that extended beyond the fence end (Fig. 2). Twenty-six (48\%) and 28 (52\%) circumventions of the outrigger fence occurred during posttreatment 1 and posttreatment 2 , respectively.
The deer whose postconstruction home range did not encompass the end of the outrigger fence (no. 16) accounted for 10 (45\%) of 22 outrigger crossings. Eight of these crossings occurred within a 1.5 -month period following fence construction, and 2 occurred on 22 October 2009. On 8 December 2009, a flood event downed a 50-m section of the outrigger fence. On 12 December 2009, deer number 16 began breaching the fence through this gap and continued to do so, almost daily, until her collar was recovered on 4 February 2010. Crossings of the fence area by this deer, after the flood event, were excluded from analysis.

Home range and core area sizes decreased from pretreatment to posttreatment 1 , and increased again during posttreatment 2 . There were no differences in home range or core area sizes among 2.4-m, outrigger, or control groups (Table 1). There was no effect of fences or treatment period on the mean of center points for each deer (Table 2).

Although deer with home ranges that overlapped the future site of the 2.4-m fence spent the majority of their time on one side of the VT during the pretreatment period, there were a small proportion of points for each deer that occurred on the opposite side (Fig. 3). However, postconstruction, the proportion of points on the opposite side declined to nearly zero for all deer except number 20, which accessed the other side by circumventing the fence during posttreatment 2 (Fig. 3). Two deer (nos. 12 and 13) showed an increase in the proportion of points in the 50 - $\mathrm{m}$ buffer closest to the fence after construction (Fig. 3). Relative to the 2.4-m fence, distributions of deer that would encounter the outrigger fence were more centered along the fence prior to construction (Fig. 4). Although the proportion of points on one side of the outrigger fence tended to decrease after its construction, the decline was not notable in 3 (nos. 1, 10, and 19) of 4 outrigger deer, because they frequently circumvented the barrier (Fig. 4). Three deer (nos. 1, 16, and 19) showed an increase in the proportion of points in the 50-m buffer region closest to the outrigger fence after construction (Fig. 4).

\section{DISCUSSION}

The reduction in crossings after fence construction suggests that both fences were sufficiently effective to examine the effects of roadside fencing on deer movements and home ranges. Although mean home range size did decrease during posttreatment 1 , this likely occurred because of fawning season, when female home ranges are typically smaller (Ozoga et al. 1982). Deer with home ranges that significantly overlapped the fence area were able to gain access to their entire home range, and avoid shifting their mean geographic center, by circumventing the fence ends. Those deer with a lesser degree of home range overlap with the fence ceased use of small portions of their home ranges, but these small changes did not result in a shift in the mean geographic center of their home ranges.

It is of particular concern that 3 of 4 deer encountering the outrigger fence, and 1 of 4 deer encountering the $2.4-\mathrm{m}$ fence, maintained use of their entire home ranges through circumvention. These deer had pretreatment home ranges that came close to or encompassed the fence endings. 


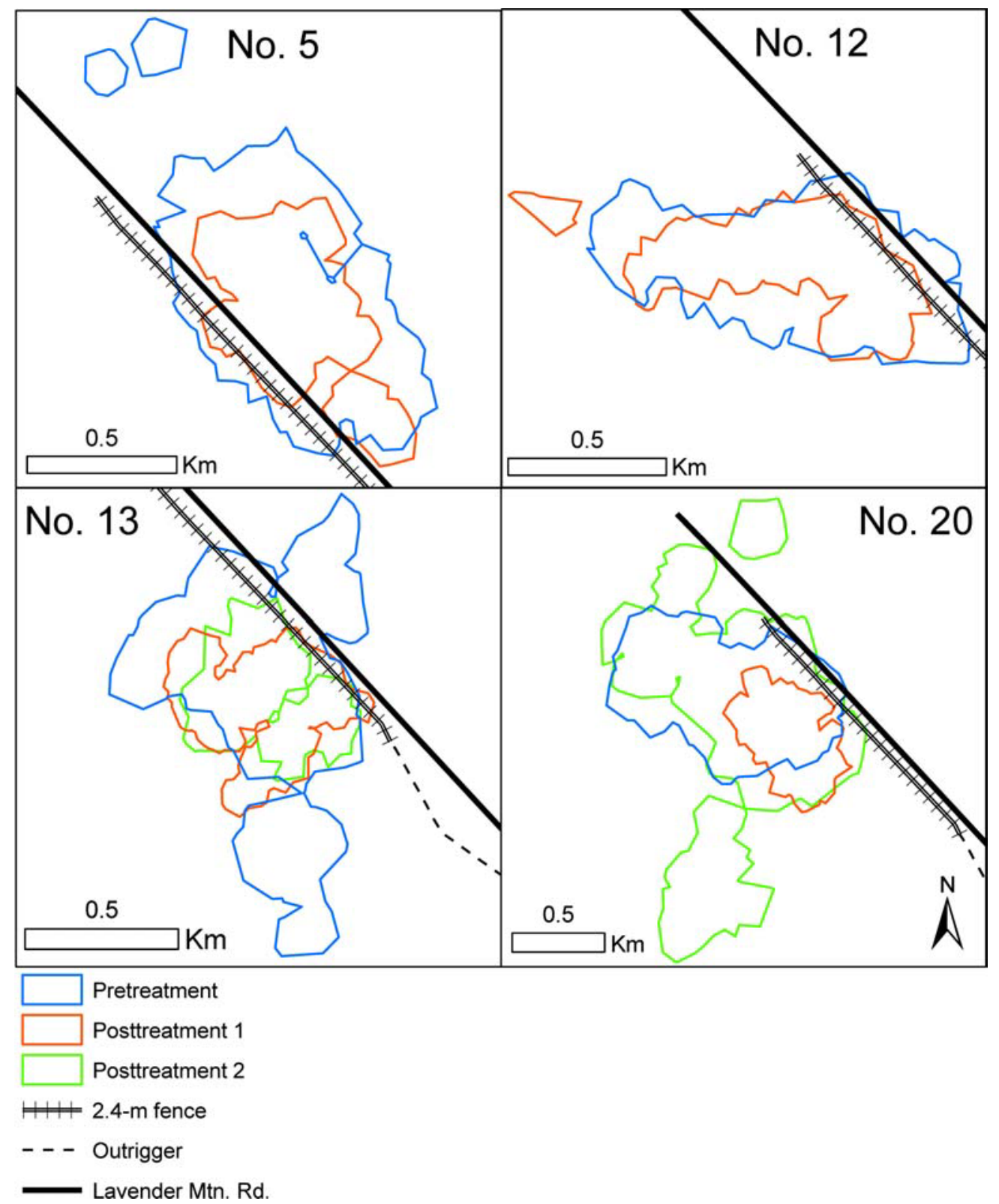

Figure 1. Ninety percent home ranges for white-tailed deer encountering a 2.4-m woven-wire fence on Berry College Wildlife Refuge in northwestern Georgia, USA. Pretreatment was from the time the deer was collared (Jan-Apr 2009) until fence construction began on 17 May 2009, posttreatment 1 was from the time fence construction was completed on 10 June 2009 until 11 September 2009, and posttreatment 2 was from 12 September 2009 until collar recovery in early 2010.

Furthermore, our finding that 5 of 8 deer showed an increase in the proportion of their point locations (i.e., time spent) just adjacent to the fence highlights the danger of implementing short lengths of DVC-mitigation fencing to treat "hot-spots" or longer stretches of fences that lack structures allowing safe crossing or escape from the roadway. This finding is in agreement with those of Ludwig and Bremicker (1981), who reported that barrier efficacy is reduced when fences are of insufficient length, because deer will circumvent the ends. In situations where fencing is not of sufficient length to extend beyond home ranges of deer in high-risk areas, crossings are concentrated at the end of the fence, thereby moving or exacerbating existing hot-spots (Knapp et al. 2004, Huijser et al. 2007).
In our study, mean pretreatment home range size was 44 ha and the mean long axis of home ranges was $1,164 \mathrm{~m}$ in length. In contrast, Rogers (1996) found that home ranges of adult females on another study site in northwestern Georgia were, on average, 6 times larger than what we observed during the same season. If long axis length increases proportionally to home range size, up to $7 \mathrm{~km}$ of fencing may be necessary to prevent circumvention by deer in this region. Furthermore, because home ranges of adult males, and both sexes of other deer species (e.g., mule deer [Odocoileus hemionus]), are typically much larger than those of the adult females in our study, extension of fences beyond the home ranges of all deer in a high-risk area may be difficult. Thus, where DVC-mitigation fencing is used as a hot-spot treat- 


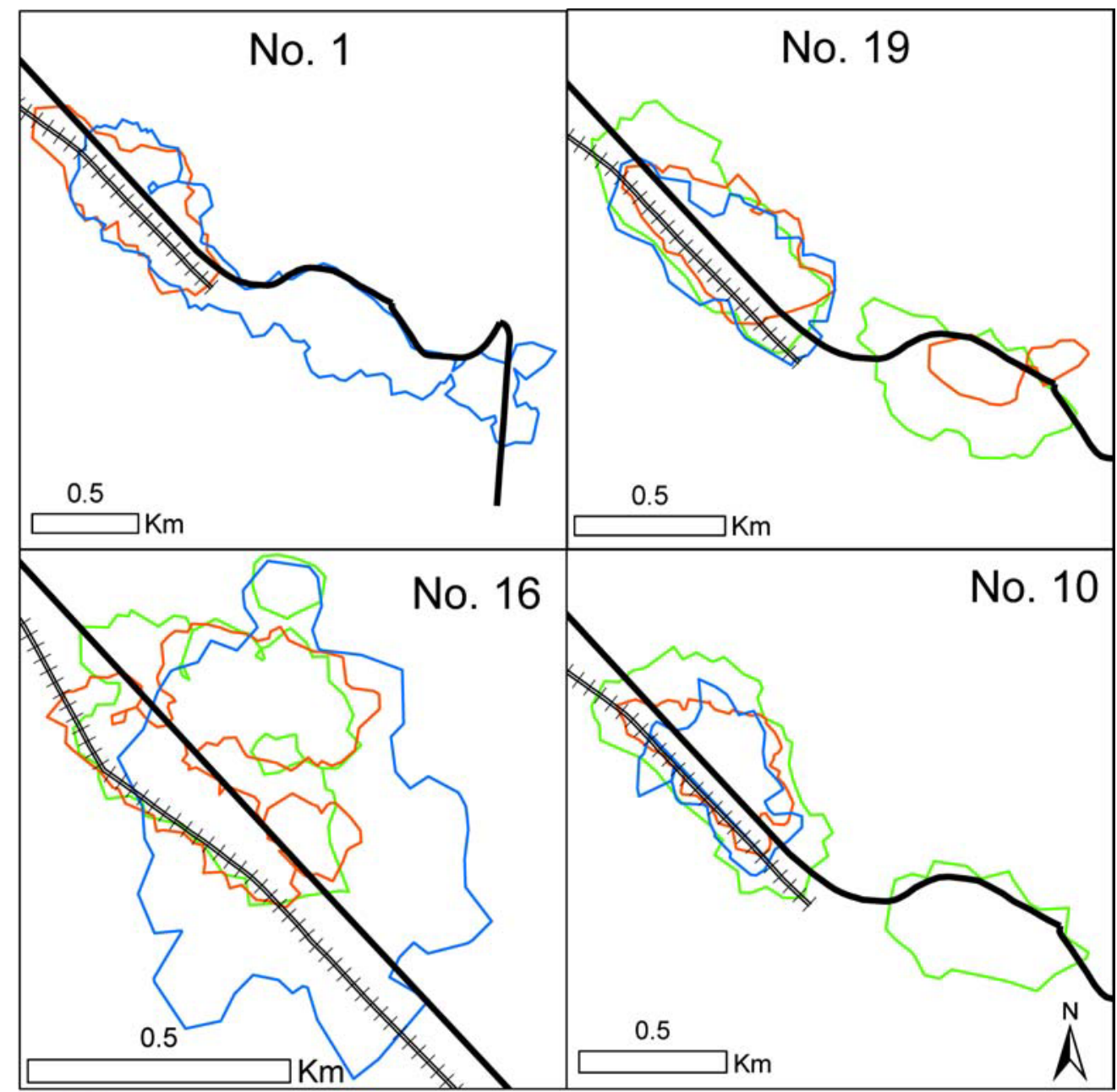

\section{Pretreatment}

Posttreatment 1

Posttreatment 2

Outrigger

\section{— Lavender Mtn. Rd.}

Figure 2. Ninety percent home ranges for white-tailed deer encountering an outrigger fence on Berry College Wildlife Refuge in northwestern Georgia, USA. Pretreatment was from the time the deer was collared (Jan-Apr 2009) until fence construction began on 17 May 2009, posttreatment 1 was from the time fence construction was completed on 10 June 2009 until 11 September 2009, and posttreatment 2 was from 12 September 2009 until collar recovery in early 2010.

Table 1. Ninety percent home range and 50\% core-area size, before and after fence construction, for white-tailed deer encountering a 2.4-m woven-wire fence $(n=4)$, outrigger fence $(n=4)$, and no fence (controls; $n=6$ ) on Berry College Wildlife Refuge in northwestern Georgia, USA from January 2009 to January 2010. Pretreatment was from the time the deer was collared (Jan-Apr 2009) until fence construction began on 17 May 2009 , posttreatment 1 was from the time fence construction was completed on 10 June 2009 until 11 September 2009, and posttreatment 2 was from 12 September 2009 until collar recovery in early 2010 .

\begin{tabular}{|c|c|c|c|c|c|c|}
\hline \multirow[b]{2}{*}{ Home range or core-area size } & \multicolumn{2}{|c|}{ Pretreatment } & \multicolumn{2}{|c|}{ Posttreatment 1} & \multicolumn{2}{|c|}{ Posttreatment 2} \\
\hline & $\bar{N}$ & Mean (SE) & $N$ & Mean (SE) & $\bar{N}$ & Mean (SE) \\
\hline \multicolumn{7}{|l|}{$90 \% a$-LoCoH home range (ha) } \\
\hline $2.4 \mathrm{~m}$ & 4 & $62(7)$ & 4 & $29(2)$ & 2 & $82(62)$ \\
\hline Outrigger & 4 & $41(14)$ & 4 & $24(5)$ & 3 & $46(7)$ \\
\hline Control & 6 & $34(7)$ & 6 & $23(3)$ & 5 & $51(9)$ \\
\hline \multicolumn{7}{|l|}{$50 \% a$ - $\mathrm{LoCoH}$ core area (ha) } \\
\hline $2.4 \mathrm{~m}$ & 4 & $17(1)$ & 4 & $8(0.3)$ & 2 & $28(21)$ \\
\hline Outrigger & 4 & $12(4)$ & 4 & $6(1)$ & 3 & $13(2)$ \\
\hline Control & 6 & $9(2)$ & 6 & $6(0.7)$ & 5 & $11(2)$ \\
\hline
\end{tabular}


Table 2. Mean distance between the mean geographic center of all point locations, from pretreatment to posttreatment 1 and from posttreatment 1 to posttreatment 2 , for white-tailed deer encountering a 2.4-m woven-wire fence, outrigger fence, and no fence (controls) on Berry College Wildlife Refuge in northwestern Georgia, USA. Pretreatment was from the time the deer was collared (Jan-Apr 2009) until fence construction began on 17 May 2009 , posttreatment 1 was from the time fence construction was completed on 10 June 2009 until 11 September 2009, and posttreatment 2 was from 12 September 2009 until collar recovery in early 2010.

\begin{tabular}{lccccc}
\hline \multirow{2}{*}{$\begin{array}{l}\text { Distance between mean } \\
\text { center of points }(\mathbf{m})\end{array}$} & \multicolumn{2}{c}{ Pre- to Post-1 } & & \multicolumn{2}{c}{ Post-1 to Post-2 } \\
\cline { 2 - 3 } & $\boldsymbol{N}$ & Mean (SE) & & $\boldsymbol{N}$ & Mean (SE) \\
\hline $2.4 \mathrm{~m}$ & 4 & $181(62)$ & & 2 & $180(139)$ \\
Outrigger & 4 & $317(152)$ & & 3 & $209(68)$ \\
Control & 6 & $153(28)$ & & 5 & $281(64)$ \\
\hline
\end{tabular}

ment, fences likely should end at natural barriers to deer movements (e.g., large bodies of water), or the fence endings must incorporate some means (e.g., wildlife overpasses or underpasses) of facilitating crossings by deer so as to avoid vehicular traffic.

Although the outrigger design we tested was designed to allow deer to escape the roadway, should they become entrapped, we found no difference in the efficacy of the outrigger fence in the outrigger-toward versus away direc- tion. Despite the fact that this finding is in disagreement with that of Stull (2009), we believe that the distance from the fence to the road (30-125 m), and the presence of cover between the two may have decreased the pressure for deer to cross in the reverse direction. In most situations where DVC-mitigation fencing is used, it is placed on both sides of the road and closer to the roadway. Deer trapped between the road and fences in those situations may be more motivated to cross than the deer in our study.

Less substantial fences, such as the outrigger fence, are typically more effective when motivation to cross is low (Goddard et al. 2001). In our study, motivation to cross likely remained low because deer maintained use of their entire home range, and the resources therein, via circumvention with the exception of deer number 16, which crossed the outrigger fence more than any other deer. The incorporation of devices such as highway overpasses or underpasses into fence designs allows deer full use of their home range without crossing the roadway.

This suggests that the outrigger fence design may be effective in situations where crossing structures are in place.

Both fencing designs were of sufficient efficacy to allow examination of their effects on deer home ranges and move-

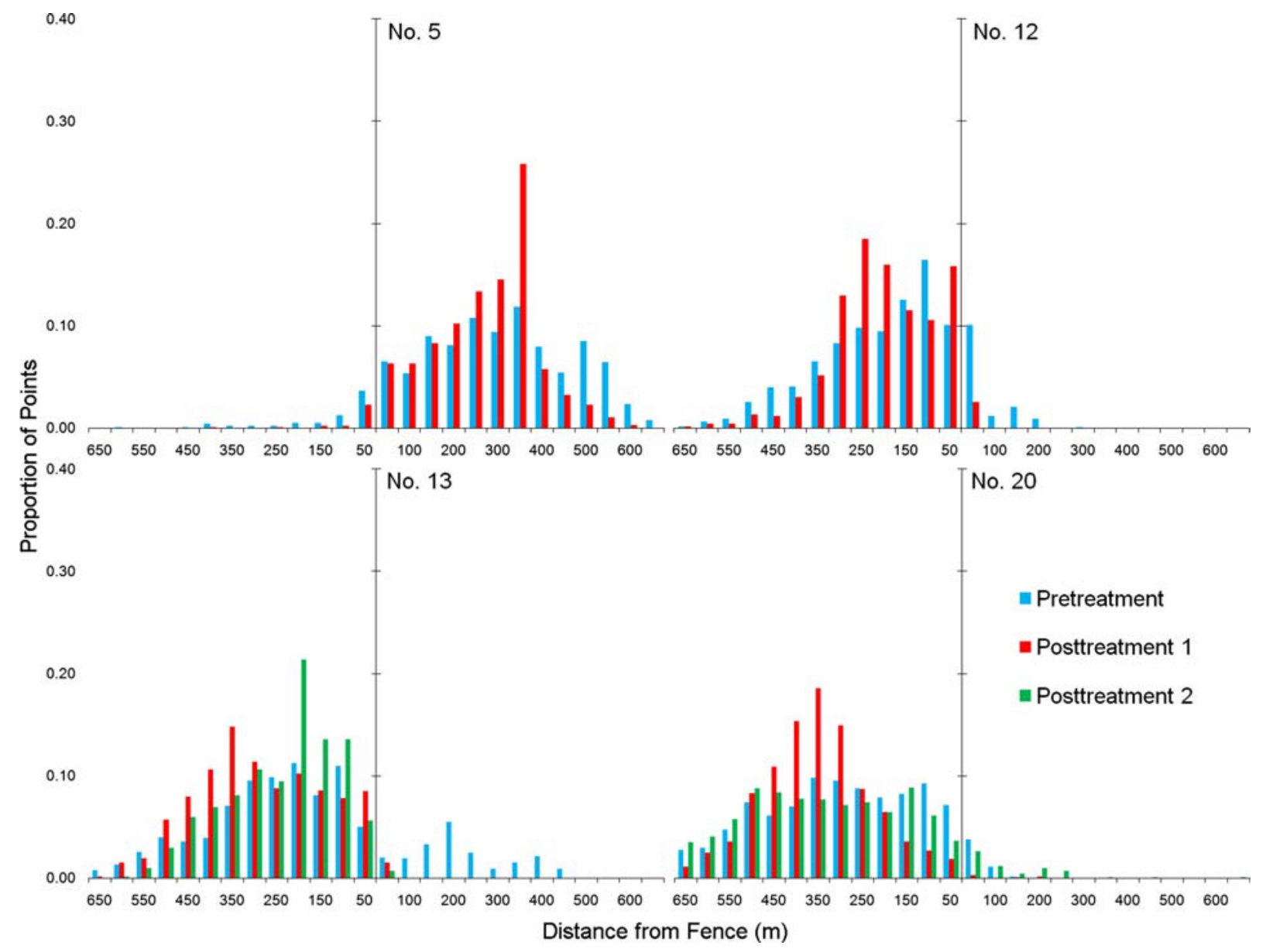

Figure 3. Distributions of point locations of white-tailed deer around a 2.4-m woven-wire fence on Berry College Wildlife Refuge in northwestern Georgia, USA. Pretreatment was from the time the deer was collared (Jan-Apr 2009) until fence construction began on 17 May 2009, posttreatment 1 was from the time fence construction was completed on 10 June 2009 until 11 September 2009, and posttreatment 2 was from 12 September 2009 until collar recovery in early 2010. The fence is represented by the vertical axis with the southwestern side to the left of it. 


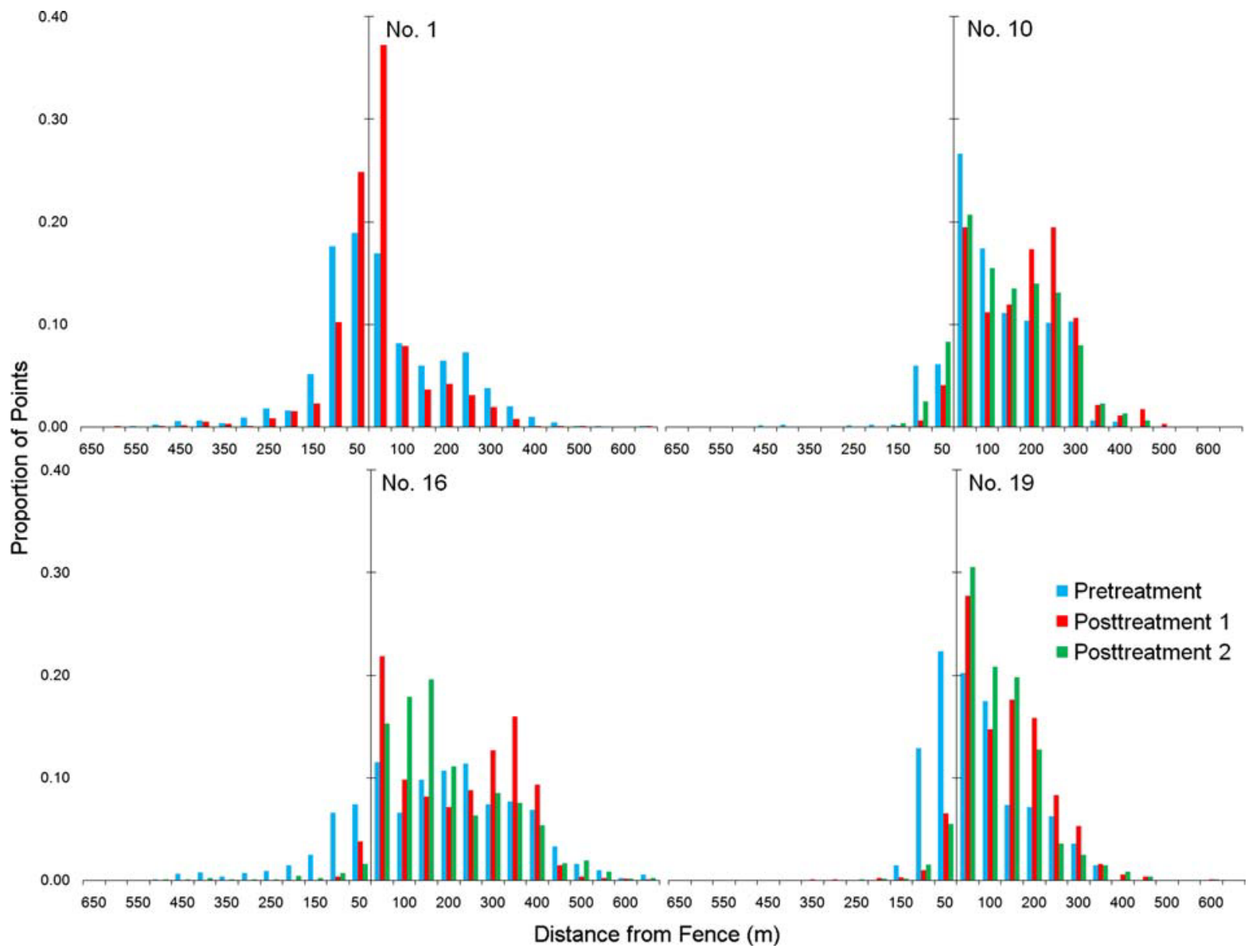

Figure 4. Distributions of point locations of white-tailed deer around an outrigger fence on Berry College Wildlife Refuge in northwestern Georgia, USA. Pretreatment was from the time the deer was collared (Jan-Apr 2009) until fence construction began on 17 May 2009, posttreatment 1 was from the time fence construction was completed on 10 June 2009 until 11 September 2009, and posttreatment 2 was from 12 September 2009 until collar recovery in early 2010 . The fence is represented by the vertical axis with the southwestern side (outrigger toward) to the left of it.

ments. However, if our fence treatments were of sufficient length to prevent circumvention, more crossings may have occurred.

\section{MANAGEMENT IMPLICATIONS}

Our results emphasize that both deer behavior and fence efficacy are important considerations when attempting to mitigate DVCs. Even fences that are highly effective at reducing deer crossings may simply relocate DVCs if they are of insufficient length. Alternately, less substantial fences may be adequate if they extend beyond deer home ranges and have crossing structures incorporated into their design. However, further research is needed to determine whether motivation of deer to cross a fence is lowered when some crossing mechanism (e.g., overpasses) is incorporated, allowing access to both sides of the roadway. Although these structures often are expensive, they may become economically feasible when combined with a less expensive exclusion fence such as the outrigger design tested herein. In addition, we recommend the use of localized data on deer home range sizes to determine the minimum length of fencing needed to prevent circumvention in high-risk areas.

Finally, because our fences were not of sufficient length to prevent circumvention, we suggest that further testing be done to assess the performance of longer stretches of outrigger fences with and without crossing structures (e.g., wildlife overpasses or underpasses) incorporated into them. In addition, future research addressing the impacts of excluding deer from former portions of their home ranges with roadside fencing should address motivation of deer to cross or circumvent barriers through quantification of important resources (i.e., food and cover).

\section{ACKNOWLEDGMENTS}

Financial assistance was provided by the Georgia Department of Transportation and the Berryman Institute (Eastern Unit). We thank Berry College for their permission to utilize their land and resources. We also thank the volunteers who helped with deer capture and monitoring as well as fence construction and maintenance.

\section{LITERATURE CITED}

Bashore, T. L., W. Tzilkowski, and E. Bellis. 1985. Analysis of deer-vehicle collision sites in Pennsylvania. Journal of Wildlife Management 49:769774.

Börger, L., N. Franconi, G. de Michele, A. Gantz, F. Meschi, A. Manica, S. Lovari, and T. Coulson. 2006. Effects of sampling regime on the mean and variance of home range size estimates. Journal of Animal Ecology 75:1393-1405. 
Bowers, J. W., A. Hammond, K. Kammermeyer, C. Martin, S. McDonald, N. Nicholson, J. Robbins, T. Touchstone, and G. Waters. 2005. Georgia's deer management plan 2005-2014. Georgia Department of Natural Resources, Wildlife Resources Division, Game Management Section, Social Circle, USA.

Bryant, L. D., J. Thomas, and M. Rowland. 1993. Techniques to construct New Zealand elk-proof fence. U.S. Department of Agriculture Forest Service Pacific Northwest Research Station. General Technical Report no. PNW-GTR-313, La Grande, Oregon, USA.

Calenge, C. 2006. The package adehabitat for the R software: a tool for the analysis of space and habitat use by animals. Ecological Modeling 197:516-519.

Carbaugh, B., J. P. Vaughan, E. D. Bellis, and H. B. Graves. 1975. Distribution and activity of white-tailed deer along an interstate highway. Journal of Wildlife Management 39:570-581.

Clevenger, A. P., B. Chruszcz, and K. E. Gunson. 2001. Highway mitigation fencing reduces wildlife-vehicle collisions. Wildlife Society Bulletin 29:646-653.

Conover, M. R., W. C. Pitt, K. K. Kessler, T. J. DuBow, and W. A. Sanborn. 1995. Review of human injuries, illnesses, and economic losses caused by wildlife in the United States. Wildlife Society Bulletin 23:407414.

Craven, S. R., and S. E. Hygnstrom. 1994. Deer. Pages D25-D40 in S. E. Hygnstrom, R. M. Timm, and G. E. Larson, editors. Prevention and control of wildlife damage. University of Nebraska Cooperative Extension, Lincoln, USA.

DeNicola, A. J., K. C. VerCauteren, P. D. Curtis, and S. E. Hygnstrom. 2000. Managing white-tailed deer in suburban environments. Cornell University Cooperative Extension, Ithaca, New York, USA.

Falk, N. W., H. B. Graves, and E. D. Bellis. 1978. Highway right-of-way fences as deer deterrents. Journal of Wildlife Management 42:646650.

Feldhamer, G. A., J. E. Gates, D. M. Harman, A. J. Loranger, and K. R. Dixon. 1986. Effects of interstate highway fencing on white-tailed deer activity. Journal of Wildlife Management 50:497-503.

Getz, W. M., S. Fortmann-Roe, P. C. Cross, A. J. Lyons, S. J. Ryan, and C. C. Wilmers. 2007. LoCoH: nonparametric kernel methods for constructing home ranges and utilization distributions. PLoS ONE 2:e207.

Getz, W. M., and C. C. Wilmers. 2004. A local nearest-neighbor convexhull construction of home ranges and utilization distributions. Ecography 27:489-505.

Goddard, P. J., R. W. Summers, A. J. MacDonald, C. Murray, and A. R. Fawcett. 2001. Behavioral responses of red deer to fences of five different designs. Applied Animal Behavioural Science 73:289-298.

Hodler, T. W., and H. A. Schretter. 1986. The atlas of Georgia. University of Georgia, Athens, USA.

Huijser, M. P., P. McGowen, J. Fuller, A. Hardy, A. Kociolek, A. P. Clevenger, D. Smith, and R. Ament. 2007. Wildlife-vehicle collision reduction study. Report to congress. U.S. Department of Transportation, Federal Highway Administration, Washington, D.C., USA.

Insurance Information Institute. 2008. <http://www.iii.org/>. Accessed 3 Dec 2008.
Isleib, J. 1995. Deer exclusion efforts to reduce crop damage in Michigan and Northeast Wisconsin. Great Plains Wildlife Damage Control Workshop 12:63-69.

Jones, M. B., and W. M. Longhurst. 1958. Overhanging deer fences. Journal of Wildlife Management 22:325-326.

Kaneene, J. B., C. S. Bruning-Fann, L. M. Granger, R. Miller, and B. A. Porter-Spalding. 2002. Environmental and farm management associated with tuberculosis on cattle farms in northeastern Michigan. Journal of the American Veterinary Medical Association 221:837-842.

Knapp, K. K., X. Yi, T. Oakasa, W. Thimm, E. Hudson, and C. Rathmann. 2004. Deer-vehicle crash countermeasure toolbox: a decision and choice resource. Midwest Regional University Transportation Center, Madison, Wisconsin, USA.

Ludwig, J., and T. Bremicker. 1981. Evaluation of 2.4-meter fences and one-way gates for reducing deer-vehicle collisions. Minnesota Wildlife Resources Quarterly 41:77-88.

Owen, M., and D. Owen. 1980. The fences of death. African Wildlife 35: 25-27.

Ozoga, J. J., L. J. Verme, and C. S. Bienz. 1982. Parturition behavior and territoriality in white-tailed deer: impacts on neonatal mortality. Journal of Wildlife Management 46:1-11.

Puglisi, M. J., J. S. Lindzey, and E. D. Bellis. 1974. Factors associated with highway mortality of white-tailed deer. Journal of Wildlife Management 38:799-807.

R Development Core Team. 2009. R: a language and environment for statistical computing. R Foundation for Statistical Computing, Vienna, Austria.

Rogers, C. L. 1996. Utilization of cedar glades by white-tailed deer at Chickamauga Battlefield Park. Thesis, University of Georgia, Athens, USA.

Romin, L. A., and J. A. Bissonette. 1996. Deer-vehicle collisions: status of state monitoring activities and mitigation efforts. Wildlife Society Bulletin 24:276-283.

Ryan, S. J., C. Knechtel, and W. M. Getz. 2006. Range and habitat selection of African buffalo in South Africa. Journal of Wildlife Management 70:764-776

Seamans, T. W. 2001. A review of deer control devices intended for use on airports. Bird Strike Committee Proceedings 21. 2001 Bird Strike Committee-USA/Canada, Third Joint Annual Meeting. Calgary, AB. Digital Commons@University of Nebraska-Lincoln. $<$ http://digitalcommons.unl.edu/>. Accessed 15 Apr 2010.

State Farm Insurance Company. 2009. < http://www.statefarm.com/>. Accessed 7 Oct 2009

Stull, D. W. 2009. Behavioral responses of captive deer to visual and physical barriers designed to reduce deer-vehicle collisions. Thesis, University of Georgia, Athens, USA.

VerCauteren, K. C., M. J. Lavelle, and S. Hygnstrom. 2006. Fences and deer-damage management: a review of designs and efficacy. Wildlife Society Bulletin 34:191-200.

Associate Editor: Porter. 